University of Nebraska - Lincoln DigitalCommons@University of Nebraska - Lincoln

Faculty Publications: School of Music

Music, School of

2016

The Framework for 21st Century Learning: A Firstrate Foundation for Music Education Assessment and Teacher Evaluation

Ashley Danielle Gilbert

Doane University, danni.gilbert@unl.edu

Follow this and additional works at: http://digitalcommons.unl.edu/musicfacpub

Part of the Music Education Commons

Gilbert, Ashley Danielle, "The Framework for 21st Century Learning: A First-rate Foundation for Music Education Assessment and Teacher Evaluation" (2016). Faculty Publications: School of Music. 70.

http://digitalcommons.unl.edu/musicfacpub/70

This Article is brought to you for free and open access by the Music, School of at DigitalCommons@University of Nebraska - Lincoln. It has been accepted for inclusion in Faculty Publications: School of Music by an authorized administrator of DigitalCommons@University of Nebraska - Lincoln. 


\title{
The Framework for 21st Century Learning: A First-rate Foundation for Music Education Assessment and Teacher Evaluation
}

\author{
Ashley Danielle Gilbert \\ Music Department, College of Arts and Sciences, Doane University, Crete, Nebraska, USA \\ Contact - Ashley Danielle Gilbert, Music Department, School of Arts and Sciences, Doane University, 1014 Boswell \\ Ave., Crete, NE 68333, USA, email danni2784@hotmail.com
}

\begin{abstract}
Federal laws and funding initiatives, such as the No Child Left Behind Act and the Race to the Top campaign, have created an increasing incentive for schools nationwide to document student progress, standardize assessment practices, and evaluate teachers according to student success. In response, the Common Core State Standards, a popular yet controversial policy, has emerged. Implemented at the state level, these standards focus heavily on the areas of English language arts and mathematics, subjects not traditionally incorporated to a great extent in music classrooms. In order for music to maintain a role as an essential subject in the school curriculum, it is imperative that music educators be able to associate themselves with a complementary initiative that allows them to demonstrate how students are meeting benchmarks required at the state and national levels without sacrificing the integrity of music instruction itself. Of the existing models available, the Framework for 21st Century Learning provides the most appropriate structure for determining music teacher effectiveness and for organizing learning objectives that can be assessed to show student growth in music education classrooms.
\end{abstract}

Keywords: assessment, Common Core State Standards, Framework for 21st Century Learning, music education, Partnership for 21st Century Skills, policy, teacher evaluation 


\section{Assessment and teacher evaluation increasingly tied to federal incentives}

In today's educational environment, the topic of assessment has been met with concern, scrutiny, debate, and, perhaps for some, fear. Federal laws such as the No Child Left Behind Act of 2001, the most recent version of the 1965 Elementary and Secondary Education Act (U.S. Department of Education 2010), and funding initiatives such as the 2010 Race to the Top campaign (Katzman 2012) have caused many educators and administrators alike to work toward improvements in demonstrated student growth and achievement in order to obtain federal incentives. Pressure is also felt at the state level as governors and state commissioners of education seek to adopt standards and policies that can guide instructional practices and assessment toward these aims.

The greatest source of anxiety for most educators, however, is teacher evaluation and the associated fear of the loss of job security. Increased use of federal funding has led schools to place the responsibility for student achievement more strongly on the shoulders of the teachers rather than the students (Reform Support Network 2013). Schools are now using indicators of student progress, such as standardized test scores, to hold teachers accountable for student learning. Standardized test scores are scrutinized and compared publicly, and are increasingly becoming the basis for determining pay cuts, raises, and contract renewals or discontinuations for teachers. Although at present, most music educators face fewer challenges associated with standardized testing and public reporting of scores compared to teachers in other subjects, they may increasingly be held responsible for how their students perform in the areas of math and language arts on standardized tests. Some states are already using math and reading test scores as indicators of teacher effectiveness in any subject, regardless of evidence of growth and progress within a teacher's specific area of specialization.

In response to this changing educational environment, the Common Core State Standards (CCSS) have emerged as an attempt to create consistency among states in terms of outlining student learning goals. This article aims to review the potential impact of the CCSS on the field of music education and illustrate how the Framework for 21st Century Learning could be a suitable alternative for music educators. The position taken here is that the Framework for 21st Century Learning provides an appropriate, first-rate structure for determining teacher effectiveness and for organizing learning objectives that can be assessed to show student growth in music education classrooms.

\section{The Common Core State Standards and music education}

Utilized at the state level for designing curriculum and subsequent assessments, the CCSS initiative seeks to provide understandable and measurable standards for all $\mathrm{K}-12$ students. In 2009, led by the National Governors Association and the Council of Chief State School Officers, work began on developing the CCSS. With the first set of standards released in 2010, the goal of the CCSS has been to provide a "single set of clear educational standards for kindergarten through 12th grade in English language arts and mathematics" in order to better prepare students to enter college or the workforce (Common Core State Standards 
Initiative 2010). Suggested benefits of adopting the CCSS include better consistency of curricula as well as efficiency in the development of materials, teacher education, and assessments (Cardany 2013). Although participation in the initiative is voluntary, states that adopted the CCSS were awarded federal funds under the 2010 Race to the Top initiative (Duncan 2013). Proponents of the CCSS anticipated full implementation of the program during the 2014-2015 school year, with assessments also available at that time (Ujifusa 2013). As of 2013, the only five states that had decided not to implement the CCSS were Nebraska, Texas, Virginia, Alaska, and Minnesota (Cardany 2013).

Common Core goals and objectives for increased knowledge in math and English language arts are intended to apply to all subjects, including music, because "they are areas upon which students build skill sets which are used in other subjects," and "they are also the subjects most frequently assessed for accountability purposes" (Common Core State Standards Initiative 2010) Teachers are asked to use their content area expertise to help students meet the particular challenges of mathematics, reading, writing, speaking, listening, and language in their respective fields (Common Core State Standards Initiative 2010). Therefore, when applying the CCSS in areas such as music classrooms, music educators must design and carry out their curricula in order to demonstrate that students are learning skills in English language arts and mathematics that can be assessed.

Despite the speedy endorsement of the CCSS by some educational leaders, there has been mounting opposition to the plan, especially from those directly involved in carrying it out. Although the CCSS initiative is state led, some fear it indicates a move toward the nationalization of curriculum (Cardany 2013). Among those who are likely to regard the CCSS as an inappropriate model are music educators who might benefit from assessing their students based on standards better suited to the arts. Some concerns of arts professionals related to the implementation of the CCSS are that the role of the arts in education may not be preserved, teachers may have to dilute the content of arts-specific curricula in order to meet the demands of the new standards, and the CCSS may not allow for the teaching of additional life skills that are fundamental to disciplines in the arts (Darrow 2014). Because music teachers must demonstrate how music objectives relate to math and language arts, the freedom they can experience when instructing within their own area of specialization may be limited, potentially sacrificing the integrity of music education as a stand-alone subject (Cardany 2013). Some worry that music instruction that "looks and sounds like [Common Core] instruction" is a "misapplication of standards," and that Common Core implementation "during music instruction may divert focus from developing music literacy" (Cardany 2013). At the K-5 level, music educators may experience less difficulty in applying the CCSS in their classrooms because they are more familiar with supporting the general academic curriculum through music (Darrow 2014). However, music educators at the secondary level, particularly those tasked with leading large performancebased ensembles, may encounter challenges associated with adapting their curricula to the aim of meeting CCSS learning objectives.

Common Core authors have developed a document entitled "Guiding Principles for the Arts" to show how to apply English language arts goals and themes to art-based learning through what they call a sustained study of limited numbers of works of art. While there are instances in which the CCSS reference the arts in general, a specifically arts-focused branch 
of the CCSS does not exist (College Board 2012). The CCSS refer to works of art, but not to music or performance-based activities specifically. In addition, the CCSS identify occasions on which students are expected to analyze, respond to, or otherwise reference works of art, but there is no discussion of actually creating or performing within these art forms. References made to music are "essentially absent," with musical terms such as "rhythm" applied in the realm of language, and specifically poetry (Cardany 2013). No apparent alignments or connections between the arts and math have been addressed. There is concern that omission of the arts from the CCSS may have a "deleterious effect on the status of music and arts education" and could negate the progress made by the profession to establish the arts as a core subject in the Goals 2000: Educate America Act of 1994 (Elpus 2013).

\section{The Framework for 21st Century Learning: A possible alternative for music educators}

Although many states have adopted the CCSS, the Framework for 21st Century Learning, a model conceptualized by the Partnership for 21st Century Skills (P21), may be a better structure for music educators to follow. The Framework for 21st Century Learning includes the arts as a core subject and illustrates plans for how to teach the arts according to twenty-first-century standards and needs. In line with this, the National Association for Music Education (NAfME) has suggested that effective teacher evaluation should include indicators of student attainment of twenty-first-century skills through instruction.

Like the CCSS, the P21 also focuses on student preparedness for life and the workforce. However, the organization includes a place for an education in the arts as well. Founded in 2002 as a coalition of business leaders and the U.S. Department of Education, which contributed \$1.5 million in matching funds, the P21 champions a fusion of the 3Rs (or core subjects, including the arts) and the $4 \mathrm{Cs}$ (critical thinking, communication, collaboration, and creativity), an approach outlined in the Framework for 21st Century Learning. Since 2002 , the organization has helped to bring national awareness to policymakers and educators of the need for twenty-first-century skills in schools. Sixteen states are currently designated as "P21 Leadership States," meaning that their governors and chief state school officers have submitted plans for blending core subjects and the 4Cs in standards, assessments, and professional development programs (Partnership for 21st Century Learning 2015).

The P21 and the CCSS are similar in that they both advocate the need to create new standards and assessments that promote student learning, success, and global competitiveness in the twenty-first century. The difference between the two programs mainly lies in the subjects they each consider to be core. While the P21 considers English language arts and mathematics to be core subjects, it also views many other subjects as distinct, of equal importance, and capable of being taught and assessed as independent disciplines. These include world languages, economics, science, geography, history, government and civics, and, most importantly for music educators, the arts (Partnership for 21st Century Skills n. d.). A study conducted in 2013 found that the status of arts education improves when equality exists in perceptions of what subjects are core (Elpus 2013). In addition, as music education leaders agreed in the 1967 Tanglewood Symposium when they called for music to be placed in the core of school curriculum, "music serves best when its integrity as an art is 
maintained" (Choate 1967, 139). Because it identifies more disciplines as core, essential subjects, the Framework for 21st Century Learning offers teachers more freedom to instruct within their content areas.

The Framework for 21st Century Learning may also be more appropriate for demonstrating congruity between standards in the arts and state-led initiatives. The philosophical principles underlying the 2014 National Core Arts Standards (a conceptual model generated for learning in dance, media arts, music, theater, and visual arts) directly address the competencies and skills that also form the basis of the P21. Five philosophical foundations and corresponding lifelong goals are considered cornerstones of the National Core Arts Standards: the arts as communication; the arts as creative personal realization; the arts as culture, history, and connectors; the arts as means to well-being; and the arts as community engagement. Based on the titles of these foundational principles alone, the National Core Arts Standards would appear to align well with the Framework for 21st Century Skills.

Communication, one of the $4 \mathrm{Cs}$, as well as one of the P21's information, media, and technology skills, is found within the National Core Arts Standards philosophical foundation of the arts as communication. Another of the $4 \mathrm{Cs}$, creativity, is embedded in the second foundational principle, the arts as creative personal realization. The arts as culture, history, and connectors principle aligns with twenty-first-century interdisciplinary themes such as global awareness, and with twenty-first-century life and career skills such as social and cross-cultural skills. Additional twenty-first-century interdisciplinary themes of health and environmental literacy align with the principle of the arts as means to well-being. Finally, the fifth National Core Arts Standards principle, the arts as community engagement, could be conceived of as the arts as collaboration. This would address yet another of the P21's 4Cs, because the "arts provide means for individuals to collaborate and connect with others" (College Board 2012). The corresponding lifelong goal of the fifth philosophical principle is that "artistically literate citizens seek artistic experience and support the arts in their local, state, national, and global communities" (College Board 2012), an aim that would also address the twenty-first-century themes of global awareness and civic literacy. Furthermore, the National Core Arts Standards leadership has stated that the activities of imagining, investigating, constructing, and reflecting "nurture the effective work habits of curiosity, creativity and innovation, critical thinking and problem solving, communication, and collaboration, each of which transfer to all aspects of learning and life in the 21st Century" (National Coalition for Core Arts Standards 2012, 7).

Influential leaders within NAfME have also expressed support of the concepts outlined in the Framework for 21st Century Skills. Scott Shuler, past president of NAfME and an arts education specialist for the Connecticut State Department of Education, has suggested ways in which music students can exhibit mastery in the 4Cs (Shuler 2011). For example, the 2014 National Core Arts Standards, which Shuler was involved in editing, call upon students to demonstrate creativity through experiences in improvisation, composition, and interpretation of music. According to Shuler $(2011,1)$, "students who learn to independently create and perform music are able to think and act creatively." Stating that "communication is arguably the primary purpose of music and the other arts," Shuler further contends that music students learn twenty-first-century communication skills through performing, creating, and responding to music. In addition, because music performance 
ensembles are a team effort for all students involved, collaboration appears to "be an almost automatic result of music study" (Shuler 2011, 1).

A model that encourages the independence of various content areas while promoting new ideas for instruction and assessment can be a great benefit to schools, especially in terms of teacher evaluation. Because the Framework is already in use, it provides a fitting structure states can refer to when implementing their own standards and ideas. In sum, the rationales supporting the Framework for 21st Century Learning as a suitable foundation for music education assessment and teacher evaluation presented in this section seem to support the position that the Framework provides appropriate first-rate structure for determining teacher effectiveness and for organizing learning objectives that can be assessed to show student growth in music education classrooms.

\section{Applying the Framework for 21st Century Learning to music education assessment and teacher evaluation}

The nature of many music classrooms already fits well with the ideas and strategies described by the P21. Because the P21 recognizes the arts, including music, as a core subject, music educators are better able to maintain the integrity of music instruction without making many changes. However, because of the demands of education in the twenty-first century, including differences in student learning styles and changes in standards and policies, music educators may need to be able to document and express ways in which their instructional practices support the Framework. If music educators can show that their methods of instruction and assessment align with the interdisciplinary model of the Framework, then teacher evaluation may prove more favorable to music educators. Luckily, many of the twenty-first-century skills that the P21 suggests are essential for students to master, such as the ability to apply technological tools effectively, are also skills that can assist teachers in documenting student growth and progress, an essential aspect of teacher evaluation.

The P21 asserts that for students to be able to succeed in work and life as adults, it is not sufficient for them to learn twenty-first-century skills by themselves (Partnership for 21st Century Learning, n.d.). Rather, it is essential that twenty-first-century skills be learned in conjunction with core knowledge and support systems. The P21 stresses that all components of the Framework are interconnected and necessary for effective learning and teaching in the twenty-first century. A graphic representation of the Framework, depicted as a rainbow illustrating student outcomes, with underlying rings of support systems, can be found at the Partnership's website (http://www.p21.org/).

The two major components of the Framework are student outcomes and support systems. Student outcomes, or skills and knowledge that students need to master in order to succeed, are divided into four sections: learning and innovation skills; life and career skills; core subjects and twenty-first-century themes; and information, media, and technology skills. Support systems are areas controlled by teachers and administrators that can influence the success of twenty-first-century students and are also divided into four sections: standards and assessment, curriculum and instruction, professional development, and learning environments. (See Appendix A for some examples of how music instruction may 
already be compatible with the Framework, as well as possible suggestions for further integration.)

Additional examples of how music can be compatible with the Framework can be found in the 21st Century Skills Map for the Arts (http://www.p21.org/our-work/resources/foreducators\#SkillsMaps) created by leaders within the P21 for each of the core subjects to provide concrete examples of how twenty-first-century skills can be integrated into the classroom. The arts skills map was designed to show educators and administrators specific examples and sample lesson plans for how twenty-first-century skills can be incorporated within the arts curriculum. This document provides sample student outcomes and examples that can be used in visual arts, dance, music, and theater classrooms for students in the fourth, eighth, and twelfth grades. Each of the twenty-first-century skills are addressed and defined, along with examples of instances in which twenty-first-century interdisciplinary themes are applied. However, these are all merely examples. In order for music educators to most effectively teach twenty-first-century skills to their students, perhaps it is best for teachers to develop their own ideas based on the needs of their students by using the 4Cs (creativity, critical thinking, communication, and collaboration) themselves in their designs for instruction and assessment. Students may have the most success when their teachers are able to be creative within the context of their subjects, leading to more fitting assessment practices and better teacher evaluation outcomes.

\section{Conclusion}

In order for music educators to effectively assess their students and to successfully withstand the increasing scrutiny of teacher evaluation, they must be able to structure their instructional and assessment practices according to a model, such as the Framework for 21st Century Learning, that allows them to work within the context of music as a core subject. Unfortunately, the widely adopted Common Core State Standards may limit the ability of music teachers to observe their students in authentic music-making activities because a stronger emphasis is placed on demonstrating student success on standardized tests in areas such as English language arts and mathematics. The Framework for 21st Century Learning recognizes music and the arts as core subjects in accordance with the 2001 No Child Left Behind Act. Because the Framework considers music an essential subject matter, music educators who are able to demonstrate student growth and progress based on the model for learning set forth by the Framework may be able to develop course content more appropriate for music education. In addition, music students may more easily develop twenty-first-century skills identified by the Framework, such as communication, collaboration, creativity, and critical thinking, when the integrity of music as a subject is maintained. These same skills are also congruent with the philosophical foundations of the 2014 National Core Arts Standards. With so many policies and standards in the midst of change, this is a timely and critical opportunity for music educators to advocate for a model such as the Framework for 21st Century Learning in order to transform the tone of assessment and teacher evaluation from uncertainty and fear to confidence and assurance. 


\section{References}

Cardany, A. B. 2013. General music and the Common Core: A brief discussion. General Music Today 27 (1): 35-39.

Choate, R., ed. 1967. Music in American society: A documentary report of the Tanglewood Symposium. Washington, DC: Music Educators National Conference.

College Board. 2012. The arts and the Common Core: A review of connections between the Common Core State Standards and the National Core Arts Standards Conceptual Framework. Accessed August 27, 2014, at http://nccas.wikispaces.com/CommonCCoreCAlignment.

Common Core State Standards Initiative. 2010. Mission statement. Accessed February 27, 2013, at www.corestandards.org.

Darrow, A. A. 2014. Applying Common Core standards to students with disabilities in music. General Music Today 27 (3): 33-35.

Duncan, A. 2013. Duncan pushes back on attacks on Common Core Standards. Speech delivered at the American Society of News Editors Annual Convention, Washington, DC. U.S. Department of Education, June 25. Accessed November 19, 2015, at http://www.ed.gov/news/speeches/duncanpushes-back-attacks-common-core-standards.

Elpus, K. 2013. Music in U.S. federal education policy: Estimating the effect of "core status" for music. Arts Education Policy Review 114 (1): 13-24.

Katzman, J. 2012. Putting the schools in charge. Education Digest 78 (4): 37-47.

National Coalition for Core Arts Standards. 2012. National Core Arts Standards: A conceptual framework for arts learning. Unpublished manuscript.

Partnership for 21st Century Learning. 2015, May. Framework for 21st Century Learning. Retrieved from http://www.p21.org/about-us/p21-framework.

Reform Support Network. 2013. Race to the Top at a glance: Evaluations of teacher effectiveness: State requirements for classroom observations. Accessed August 27, 2014, at http://www2.ed.gov/ about/inits/ed/implementation-support-unit/tech-assist/evaluations-teacher-effectiveness.pdf.

Shuler, S. 2011. The three artistic processes: Paths to lifelong 21st century skills through music. Music Educators Journal 97 (4): 9-13.

Ujifusa, A. 2013. Pressure mounts in some states against Common Core: Opponents of Common Core redouble legislation efforts. Education Week, February 13. Accessed November 19, 2015, at http://www .edweek.org/ew/articles/2013/02/06/20commoncore_ep.h32.html.

U.S. Department of Education. 2010. Obama administration's education reform plan emphasizes flexibility, resources and accountability for results [press release]. U.S. Department of Education Press Room, March 15. Accessed November 19, 2015, at http://www2.ed.gov/news/pressreleases/ 2010/03/03152010.html. 


\section{Appendix A}

\section{Applying the Framework for 21st Century Learning to music instruction}

\begin{tabular}{|c|c|}
\hline Framework Component & Use in Music Classroom \\
\hline $\begin{array}{l}\text { Student Outcomes } \\
\text { - Learning and innovation skills (4Cs) } \\
\text { - Communication } \\
\text { - Collaboration } \\
\text { - Communication } \\
\text { Critical thinking }\end{array}$ & $\begin{array}{l}\text { - Students communicate when performing or } \\
\text { responding to music. } \\
\text { - Students collaborate when performing or rehearsing } \\
\text { together. } \\
\text { - Students can create through composing or improvising. } \\
\text { - Students can use critical thinking when interpreting or } \\
\text { evaluating music. }\end{array}$ \\
\hline Life and career skills & $\begin{array}{l}\text { - Students are able to manage goals and time, work } \\
\text { independently, and become self-directed learners } \\
\text { through individual practice. } \\
\text { - Students learn leadership and responsibility by } \\
\text { working in groups or through ensemble work. }\end{array}$ \\
\hline $\begin{array}{l}\text { Core subjects (music) and twenty-first-century } \\
\text { themes } \\
\text { - Global awareness } \\
\text { - Financial, economic, business, and } \\
\text { entrepreneurial literacy } \\
\text { - Civic literacy } \\
\text { - Health literacy } \\
\text { - Environmental literacy }\end{array}$ & $\begin{array}{l}\text { - Students can develop global awareness by performing } \\
\text { multicultural music or through distance learning } \\
\text { (e.g., Skype in the Classroom; see https://education } \\
\text {.skype.com/). }\end{array}$ \\
\hline Information, media, and technology skills & $\begin{array}{l}\text { - Students are given opportunities to use a variety of } \\
\text { technological tools appropriately and effectively. } \\
\text { - Students understand ethical and legal issues } \\
\text { associated with music. } \\
\text { - Students are able to access information about music } \\
\text { efficiently using different sources of media and digital } \\
\text { technology. }\end{array}$ \\
\hline $\begin{array}{l}\text { Support Systems } \\
\text { Standards and assessments }\end{array}$ & $\begin{array}{l}\text { - Teachers apply current and developing national } \\
\text { music standards to instruction and assessment. } \\
\text { - Teachers use technology to develop portfolios of student } \\
\text { work, demonstrating growth and achievement. }\end{array}$ \\
\hline Curriculum and instruction & $\begin{array}{l}\text { - Teachers incorporate twenty-first-century skills } \\
\text { within context of music subject. } \\
\text { - Teachers integrate a variety of appropriate technologies } \\
\text { and community/global resources into instruction. }\end{array}$ \\
\hline Professional development & $\begin{array}{l}\text { Teachers engage in professional learning networks } \\
\text { and communities in person and online. }\end{array}$ \\
\hline Learning environments & $\begin{array}{l}\text { - Teachers share best practices in music education to } \\
\text { create optimal learning environments for students. } \\
\text { - Teachers provide access to current and applicable } \\
\text { technology. } \\
\text { - Teachers design physical and virtual layout of } \\
\text { classroom to promote student-centered learning. }\end{array}$ \\
\hline
\end{tabular}

